Karen M. Barry • Rie Mihara • Noel W. Davies

Tohru Mitsunaga $\cdot$ Caroline L. Mohammed

\title{
Polyphenols in Acacia mangium and Acacia auriculiformis heartwood with reference to heart rot susceptibility
}

\begin{abstract}
The heartwood of Acacia mangium is vulnerable to heart rot and this is the first study to investigate the role of heartwood extractives in its susceptibility. Acacia auriculiformis was compared with A. mangium because it is rarely associated with heart rot. The heartwood extracts of both species were dominated by three flavonoids $(2,3-$ trans-3,4',7,8-tetrahydroxyflavanone, teracacidin, and $4^{\prime}, 7,8$,-trihydroxyflavanone), which were purified and identified by nuclear magnetic resonance spectroscopy. The latter compound has not been previously reported in $A$. mangium and evidence for melacacidin is also newly reported. The mass spectrometric (MS) behavior of these compounds is given, for example teracacidin does not form molecular ions by either electrospray ionization or atmospheric-pressure chemical ionization. The nature of Acacia tannins was compared to quebracho tannin (composed of profisetinidins) using oxidative cleavage to enable MS detection but a negative reaction was obtained for both, which suggests the Acacia tannins may also be of the 5-deoxy proanthocyanidin type. The concentration of flavanones was less when $A$. mangium heartwood was decayed but the amount of proanthocyanidins was only slightly reduced and therefore these compounds may be more resistant to degradation by heart rot fungi. We found that the total phenol
\end{abstract}

K.M. Barry $(\bowtie)$

School of Agricultural Science, University of Tasmania, Private Bag

54, Hobart 7001, Tasmania, Australia

Tel. +61-3-62267995; Fax +61-3-62367901

e-mail: Karen.Barry@ffp.csiro.au

K.M. Barry · C.L. Mohammed

CRC for Sustainable Production Forestry, Hobart 7001, Tasmania, Australia

R. Mihara · T. Mitsunaga

Faculty of Bioresources, Mie University, 1515 Kamihama, Tsu 514-8507, Japan

N.W. Davies

Central Science Laboratory, University of Tasmania, Hobart 7001, Tasmania, Australia

C.L. Mohammed

CSIRO Forestry and Forest Products, Hobart 7001, Tasmania,

Australia content of $A$. auriculiformis was about fivefold that of $A$. mangium, and, while preliminary, this provides evidence for a role played by phenolic extractives in heart rot resistance of these Acacia species.

Key words Flavanones - Proanthocyanidins - LCMS · Acacia spp. Heart rot

\section{Introduction}

Acacia mangium is an important hardwood plantation tree grown in many areas of Asia, representing over 1 million ha of land use in the region. ${ }^{1}$ One of the major impediments to using $A$. mangium for solid wood products is the prevalence of heart rot, which is fungal decay of heartwood in living trees. ${ }^{2-4}$ Field studies have revealed that while A. mangium trees are susceptible to heart rot, Acacia auriculiformis and hybrids between the two species appear to be resistant. ${ }^{5,6}$ Smaller branch sizes of $A$. auriculformis have been suggested as a basis for the lower incidence of heart $\operatorname{rot}^{5}$ because infection is established mostly through dead stubs and branches. ${ }^{5,7}$ However, little research has been conducted on other factors that relate to decay resistance such as wood properties and extractives. The durability of heartwood in living trees is determined by a number of factors such as density, lignin content and type, water content, and especially extractives. ${ }^{8,9}$

Wood extractives from a variety of species of the large Acacia genus have been characterized and this has been thoroughly reviewed by Seigler. ${ }^{10}$ Acacia heartwoods are dominated by flavonoids and proanthocyanidins (condensed tannins) with similar hydroxylation patterns. ${ }^{11}$ A diversity of proanthocyanidin (PA) types have been found in acacia wood including procyanidins, profisetinidins (Fig. 1), prorobinetinidins, prodelphinidins, and proteracacinidins. ${ }^{10-12}$ There have been few studies on the chemistry of $A$. mangium and $A$. auriculiformis heartwood extractives. Only two major flavonoids have been reported in A. mangium healthy heartwood, ${ }^{13,14}$ which are 2,3- 


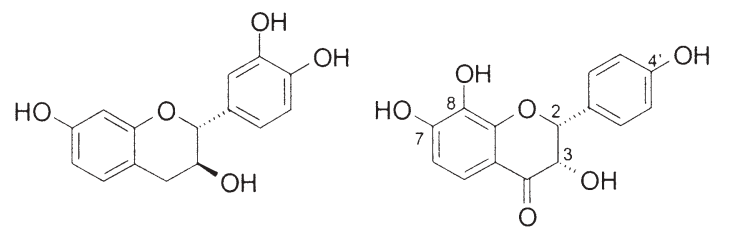

Profisetinidin monomeric unit (M.W. 274)

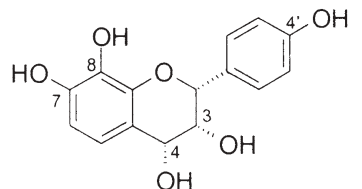

Teracacidin

(M.W. 290), compound III 2,3-cis-3,4',7,8tetrahydroxyflavanone (M.W. 288)

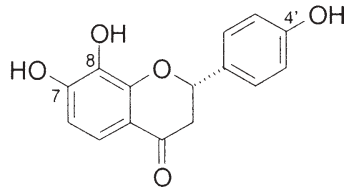

4', 7,8-trihydroxyflavanone (M.W. 272), compound II

Fig. 1. Structure of flavonoids found in Acacia mangium and Acacia auriculiformis and the profisetinidin subunit

cis-3,4', 7,8-tetrahydroxyflavanone and teracacidin (Fig. 1). In $A$. auriculiformis heartwood, eight flavonoids have been identified, all having the 4',7,8-hydroxylation pattern, and include isoteracacidin (the 2,3-cis-3,4-trans isomer) and 4',7,8-trihydroxyflavanone (Fig. 1), in addition to the two reported for A. mangium. ${ }^{15}$

The aim of our studies was to characterize major compounds and conduct preliminary quantification of the wood extractives of A. mangium and A. auriculiformis, with emphasis on the wood from living trees rather than wood products. The nature of the condensed tannins has never been reported for either species. Quantitative comparison of the extracts between the two species also remains unreported to date. These studies are important to explore the role of extractives in heart rot resistance. Analysis of heartrotted wood is also valuable to establish which compounds are degraded by the fungi and which are not. In addition to the methods of high performance liquid chromatography (HPLC) and nuclear magnetic resonance (NMR) spectroscopy used by Tachi et al., ${ }^{13}$ we used mass spectrometry with both electrospray ionization (ESI) and atmospheric pressure chemical ionization (APCI) to assist compound identification.

\section{Experimental}

Plant material

Australia. Wood samples were prepared from two 7-yearold trees each of freshly harvested $A$. mangium and $A$. auriculiformis grown in northern Queensland (Meunga, near Cardwell), where each species was grown in a hybridizing trial. ${ }^{16}$ A. mangium tree 1 was seedlot 19256 from a Fiji seed production area. The Fiji orchard was dominated by seed collections from the Western Province in Papua New Guinea (PNG). This tree had a small amount of heart rot

but this was not near the heartwood sampled. Tree 2 was from CSIRO seedlot 17701 from the Claudie River in North Queensland. Both A. auriculiformis trees were from seedlot 19514 from a Melville Island seed orchard, which was based on seed from south-west PNG.

Indonesia. Wood samples were prepared from six freshly harvested $A$. mangium trees in plantations from two different regions of Sumatra (four trees in Riau and two in South Sumatra provinces). The trees were all 8 years old. The seed source of trees grown in these regions and descriptions of the soil and climate, have been described elsewhere. ${ }^{4}$ Freshly harvested logs of trees with and without heart rot were sampled.

\section{Extractions}

Large-scale extracts were prepared from heartwood of the four trees from Australia. Billets of wood were cut from $2 \mathrm{~m}$ above ground level directly after harvest. The wood was dried at $30-35^{\circ} \mathrm{C}$ in the dark, cut into disks, split, and then ground through a $1-\mathrm{mm}$ mesh in a Wiley mill (Thomas Wiley Mill Model 4, Arthur H. Thomas Company, USA). The dried, ground heartwood (ca. $600 \mathrm{~g}$ ) was extracted in $3.51 \times 2$ of $100 \%$ methanol $(\mathrm{MeOH})$ at room temperature on a shaker in the dark. Each extraction was for 2 days and extracts were then filtered through a Whatman No. 5 filter paper. Extracts were taken to dryness on a rotary evaporator at $40^{\circ} \mathrm{C}$.

Small-scale extracts were prepared from Indonesian plant material. Billets of wood were transported from the field in ice boxes and taken immediately to a laboratory (within $1 \mathrm{~h}$ ). Samples of healthy sapwood, healthy inner and outer heartwood, and decayed and discolored heartwood were prepared using a chisel to make thin $(<1 \mathrm{~mm})$ shavings. These were weighed (ca. $100 \mathrm{mg}$ fresh weight) and extracted in $1.5 \mathrm{ml} \times 2$ of $70 \%$ aqueous acetone. Each extraction was for $24 \mathrm{~h}$ at $4^{\circ} \mathrm{C}$ in the dark. Samples were then stored at $-20^{\circ} \mathrm{C}$ until being transported to Hobart for analysis.

\section{Fractionation and isolation}

The large-scale extracts of tree 2 of both species were fractionated and purified using a schedule adapted from Tachi et al. ${ }^{13}$ Thirteen grams of the bulk $\mathrm{MeOH}$ extract was dissolved in $10 \mathrm{ml}$ of $\mathrm{MeOH}$ and extracted with 11 of diethyl ether, ethyl acetate, and $n$-butanol, successively. Each successive extraction was performed at room temperature over $2 \mathrm{~h}$. The three fractions and residue obtained are referred to as fractions $\mathrm{A}, \mathrm{B}, \mathrm{C}$, and $\mathrm{D}$ respectively.

For the A. mangium extract, fraction A $(2 \mathrm{~g})$ was dissolved in $n$-hexane/acetone $(1 / 1, \mathrm{v} / \mathrm{v})$ and applied to a silica gel 60 column (Merck, Australia, $5 \mathrm{~cm}$ i.d. $\times 26 \mathrm{~cm}$ ) and then eluted with $n$-hexane/acetone (7/3 and 5/5, v/v) and $\mathrm{MeOH}$. The $n$-hexane/acetone $(5 / 5, \mathrm{v} / \mathrm{v})$ eluate was separated into three fractions and therefore five fractions were obtained in total (A-30, A-50-1, A-50-2, A-50-3 and M-100). The fraction A-50-3 was then further purified by preparative thin 
layer chromatography (TLC) to isolate I and II $\left(R_{\mathrm{f}} 0.16\right.$ and 0.36). Preparative TLC was completed using silica gel 60 plates (Merck, Germany) with a $\mathrm{MeOH} /$ dichloromethane (8/92) solvent. Bands were visualized with ultraviolet (UV) light $(254 \mathrm{~nm})$.

For A. auriculiformis, fraction A ( $3 \mathrm{~g})$ was dissolved in $300 \mathrm{ml}$ of ethyl acetate and extracted with $200 \mathrm{ml} \times 3$ of water using a separation funnel. The water layer was collected and freeze-dried. To isolate III, the water-soluble fraction was further purified by preparative HPLC with a reversed phase Develosil ODS-10 column $(20 \mathrm{~mm}$ i.d. $\times$ $250 \mathrm{~mm}$, Nomura chemical, Japan) monitored at $280 \mathrm{~nm}$. The solvent system used was as follows: a linear gradient elution for $40 \mathrm{~min}$ from $15 \%$ to $60 \%$ solvent $\mathrm{B}(\mathrm{MeOH})$ in solvent A $\left[0.01 \%\right.$ trifluoroacetic acid (TFA) in $\left.\mathrm{H}_{2} \mathrm{O}\right]$ at a flow rate of $10 \mathrm{ml} \mathrm{min}^{-1}$.

Nuclear magnetic resonance (NMR) spectroscopy

${ }^{1} \mathrm{H}-\mathrm{NMR}$ and ${ }^{13} \mathrm{C}$-NMR were recorded on a Jeol ALPHA500 spectrometer (Jeol Tokyo, Japan). Chemical shifts are given in $\delta$ values (parts per million), based on the ${ }^{1} \mathrm{H}$ and ${ }^{13} \mathrm{C}$ signals of the solvent (acetone- $d_{6}: \delta_{\mathrm{H}} 2.04, \delta_{\mathrm{C}} 29.8$ ).

Compound I. MS $m / z: 287[\mathrm{M}-\mathrm{H}]^{-}, 289[\mathrm{M}+\mathrm{H}]^{+} .{ }^{1} \mathrm{H}-\mathrm{NMR}$ $\left(500 \mathrm{MHz}\right.$, acetone- $\left.d_{6}\right): \delta 4.59(1 \mathrm{H}, \mathrm{d}, J=12 \mathrm{~Hz}, \mathrm{H}-2), 5.06$ $(1 \mathrm{H}, \mathrm{d}, J=12 \mathrm{~Hz}, \mathrm{H}-3), 6.67(1 \mathrm{H}, \mathrm{d}, J=8.5 \mathrm{~Hz}, \mathrm{H}-6), 6.91$ $\left(2 \mathrm{H}, \mathrm{d}, J=8.5 \mathrm{~Hz}, \mathrm{H}-3^{\prime}, 5^{\prime}\right), 7.33(1 \mathrm{H}, \mathrm{d}, J=8.5 \mathrm{~Hz}, \mathrm{H}-5), 7.44$ $\left(2 \mathrm{H}, \mathrm{d}, J=8.5 \mathrm{~Hz}, \mathrm{H}-2^{\prime}, 6^{\prime}\right) .{ }^{13} \mathrm{C}-\mathrm{NMR}(125 \mathrm{MHz}$, acetone$\left.d_{6}\right): \delta 74.12(\mathrm{C}-2), 85.21(\mathrm{C}-3), 111.20(\mathrm{C}-6), 113.62(\mathrm{C}-4 \mathrm{a})$, 115.79 (C-3', 5'), 119.06 (C-5), 129.25 (C-1'), 130.48 (C-2', 6'), 133.46 (C-8), 151.54 (C-8a), 153.18 (C-7), 158.74 (C-4'), $193.64(\mathrm{C}-4)$.

Compound II. MS $m / z: 271[\mathrm{M}-\mathrm{H}]^{-}, 273[\mathrm{M}+\mathrm{H}]^{+} .{ }^{1} \mathrm{H}-$ NMR $\left(500 \mathrm{MHz}\right.$, acetone- $\left.d_{6}\right): \delta 2.67(1 \mathrm{H}, \mathrm{dd}, J=17,2.5 \mathrm{~Hz}$, H-3a), $3.08(1 \mathrm{H}, \mathrm{dd}, J=17,12.5 \mathrm{~Hz}, \mathrm{H}-3 \mathrm{~b}), 5.46(1 \mathrm{H}, \mathrm{dd}, J=$ $12.5,2.5 \mathrm{~Hz}, \mathrm{H}-2), 6.61(1 \mathrm{H}, \mathrm{d}, J=8.5 \mathrm{~Hz}, \mathrm{H}-6), 6.91(2 \mathrm{H}, \mathrm{d}$, $\left.J=8.5 \mathrm{~Hz}, \mathrm{H}-3^{\prime}, 5^{\prime}\right), 7.32(1 \mathrm{H}, \mathrm{d}, J=8.5 \mathrm{~Hz}, \mathrm{H}-5), 7.42(2 \mathrm{H}$, $\left.\mathrm{d}, J=8.5 \mathrm{~Hz}, \mathrm{H}-2^{\prime}, 6^{\prime}\right) .{ }^{13} \mathrm{C}-\mathrm{NMR}\left(125 \mathrm{MHz}\right.$, acetone- $\left.d_{6}\right)$ : $\delta 44.92$ (C-3), 81.06 (C-2), 110.51 (C-6), 115.70 (C-4a), 116.07 (C-3', 5'), 118.73 (C-5), 129.12 (C-2', 6'), 131.17 (C1'), 133.54 (C-8), 151.65 (C-7), 152.53 (C-8a), 158.60 (C-4'), 190.87 (C-4).

Compound III. MS $m / z: 273\left[\mathrm{M}-\mathrm{H}_{2} \mathrm{O}+\mathrm{H}\right]^{+},{ }^{1} \mathrm{H}-\mathrm{NMR}$ $\left(500 \mathrm{MHz}\right.$, acetone- $\left.d_{6}\right): \delta 3.99(1 \mathrm{H}, \mathrm{d}, J=4.0 \mathrm{~Hz}, \mathrm{H}-3), 4.95$ $(1 \mathrm{H}, \mathrm{d}, J=4.0 \mathrm{~Hz}, \mathrm{H}-4), 5.11(1 \mathrm{H}, \mathrm{s}, \mathrm{H}-2), 6.47(1 \mathrm{H}, \mathrm{d}, J=$ $8.5 \mathrm{~Hz}, \mathrm{H}-6), 6.82\left(2 \mathrm{H}, \mathrm{d}, J=8.5 \mathrm{~Hz}, \mathrm{H}-3^{\prime} 5,5^{\prime} 5\right), 6.86(1 \mathrm{H}, \mathrm{d}$, $J=8.5, \mathrm{H}-5), 7.42\left(2 \mathrm{H}, \mathrm{d}, J=8.5, \mathrm{H}-2^{\prime}, 6^{\prime}\right) .{ }^{13} \mathrm{C}-\mathrm{NMR}$ $\left(125 \mathrm{MHz}\right.$, acetone- $\left.d_{6}\right): \delta 68.1(\mathrm{C}-4), 70.3(\mathrm{C}-3), 79.8(\mathrm{C}-2)$, 109.0 (C-6), 115.4 (C-3', 5'), 117.2 (C-4a), 118.7 (C-5), 129.5 (C-2', 6'), 130.8 (C-1'), 132.7 (C-8), 143.7 (C-8a), 145.7 (C7), $157.8\left(\mathrm{C}-4^{\prime}\right)$.

\section{Colorimetric assays}

Total phenols were estimated by the Folin-Ciocalteu method as described previously. ${ }^{17}$ Concentrations of total phenols were calculated with reference to a gallic acid standard curve.

A vanillin-hydrochloric acid colorimetric assay was used to determine flavanol content and was conducted with our previous method. ${ }^{18}$

To determine tannins, a protein precipitation method using bovine serum albumin (BSA, Wako, Japan) was used. This method was adapted from Kawamoto et al., ${ }^{19}$ and analyzed the BSA content of the supernatant liquid rather than the BSA content of precipitation. A $200-\mu$ l volume of extract solution $\left(2 \mathrm{mg} \mathrm{ml}^{-1}\right.$, dissolved in $50 \%$ aqueous ethanol) was added to $200 \mu \mathrm{l}$ of BSA solution $\left(2 \mathrm{mg} \mathrm{ml}^{-1}\right.$, dissolved in $0.1 \mathrm{M}$ acetate buffer, $\mathrm{pH} 5$ ). After reacting at room temperature for $1 \mathrm{~h}$, the solution was centrifuged $(13000 \times \mathrm{g}$, $2 \mathrm{~min})$. The remaining BSA in the supernatant was determined by HPLC (CLASS M10A, Shimadzu, Japan) with a reversed phase Develosil 300 C4-HG-5 column $(4.6 \mathrm{~mm}$ i.d. $\times 150 \mathrm{~mm}$, Nomura chemical, Japan) monitored at $280 \mathrm{~nm}$. The solvent system used was as follows: a linear gradient elution for $20 \mathrm{~min}$ from $20 \%$ to $80 \%$ solvent B ( $90 \%$ aqueous $\mathrm{CH}_{3} \mathrm{CN}$ containing $0.01 \%$ TFA) in solvent $\mathrm{A}(0.01 \%$ TFA in $\mathrm{H}_{2} \mathrm{O}$ ) at flow rate of $1 \mathrm{mlmin}^{-1}$. The column temperature was $35^{\circ} \mathrm{C}$.

\section{HPLC-MS analysis}

HPLC separations were carried out on a Waters Alliance 2690 using a Waters Nova Pak C18 column $(3.9 \mathrm{~mm}$ i.d. $\times$ $150 \mathrm{~mm}$ ). The mobile phase used three prepared solvents: A (water/acetic acid 98:2), B (MeOH/acetic acid 98:2), and C (100\% $n$-hexane). The program used a linear gradient from initial conditions of $90 \% \mathrm{~A}$ and $10 \% \mathrm{~B}$ to $100 \% \mathrm{~B}$ over $6 \mathrm{~min}$, then to $85 \% \mathrm{~B}$ and $15 \% \mathrm{C}$ for $25 \mathrm{~min}$. The flow rate was $0.8 \mathrm{ml} \mathrm{min}^{-1}$. Compounds were detected with a Waters 996 Photo-Diode Array detector, monitoring the range of 240-400 nm.

Mass spectrometry was carried out on a Finnigan LCQ (San Jose, CA, USA) with either electrospray ionization (ESI) or atmospheric-pressure chemical ionization (APCI) in either negative or positive ion mode using LCQ Navigator Version 1.2 software. The range from $\mathrm{m} / \mathrm{z}$ 125 to 1500 was scanned, with an AGC target value of $2 \times$ $10^{7}$ and maximum ion injection time of $100 \mathrm{~ms}$. The ESI operating conditions have been previously described. ${ }^{20}$ APCI operating conditions were: sheath gas $50 \mathrm{psi}$, aux gas $5 \mathrm{psi}$, source current $6 \mu \mathrm{A}$, capillary temperature $180^{\circ} \mathrm{C}$, svaporizer temperature $460^{\circ} \mathrm{C}$, capillary voltage $-10 \mathrm{~V}$. Data-dependent MS-MS spectra were recorded as described above.

Semiquantification of individual compounds and proanthocyanidin-like polymers was performed using a rutin internal standard (Sigma, Sydney) with UV detection at $280 \mathrm{~nm}$. To identify minor compounds (not purified and identified by NMR), HPLC retention times, UV spectra, 
Table 1. Yield, total phenols, flavanol content, and tannin content for the large-scale methanol extracts and derived fractions of Acacia mangium and Acacia auriculiformis

\begin{tabular}{|c|c|c|c|c|}
\hline Sample & Yield $(\%)^{\mathrm{a}}$ & Phenol content $(\%)^{\mathrm{b}, \mathrm{c}}$ & Flavanol content $(\%)^{\mathrm{b}, \mathrm{d}}$ & Tannin content $(\mu \mathrm{g} \mathrm{BSA} / 400 \mu \mathrm{g} \text { extract })^{\mathrm{e}}$ \\
\hline \multicolumn{5}{|l|}{ Acacia mangium } \\
\hline Bulk extract (1) & 2.93 & 28.50 & NA & NA \\
\hline Bulk extract (2) & 3.95 & 31.78 & 0.77 & 150.71 \\
\hline Fraction A (2) & 0.94 & 38.39 & 2.10 & 25.71 \\
\hline Fraction B (2) & 0.43 & 56.57 & 0.64 & 248.00 \\
\hline Fraction C (2) & 0.37 & 21.29 & 0 & 320.96 \\
\hline Fraction D (2) & 0.35 & 8.58 & 0 & 257.93 \\
\hline \multicolumn{5}{|c|}{ Acacia auriculiformis } \\
\hline Bulk extract (1) & 9.30 & 43.30 & NA & NA \\
\hline Bulk extract (2) & 7.99 & 76.59 & 2.56 & 83.67 \\
\hline Fraction A (2) & 4.54 & 75.96 & 0 & 9.24 \\
\hline Fraction B (2) & 1.04 & 64.65 & 0 & 14.56 \\
\hline Fraction C (2) & 0.82 & 20.85 & 2.73 & 78.69 \\
\hline Fraction D (2) & 0.03 & 6.55 & 0.27 & 3.04 \\
\hline
\end{tabular}

Figures in parentheses indicate tree number

NA, data not available; BSA, bovine serumalbumin

${ }^{a}$ Per dry weight of wood extracted

${ }^{\mathrm{b}}$ Per dry weight of methanol extract

${ }^{\mathrm{c}}$ Folin-Ciocalteu assay

${ }^{\mathrm{d}}$ Vanillin-HCL test

${ }^{\mathrm{e}}$ BSA assay

and MS data were used. Melacacidin from an Acacia melanoxlyon extract was used as a standard.

\section{Depolymerization}

Depolymerization of the acacia tannins was attempted by oxidative cleavage of the interflavan bond and nucleophilic trapping by phloroglucinol. ${ }^{21,22}$ Bulk extract, fractions, or purified teracacidin (ca. $20 \mathrm{mg}$ ) was dissolved in $100 \mu \mathrm{l}$ of $50 \%$ aqueous ethanol and placed in a 5-ml glass reaction vial (Alltech). To this $300 \mu \mathrm{l}$ of phloroglucinol reagent ( $80 \mathrm{mg}$ phloroglucinol in $0.5 \mathrm{ml} \mathrm{MeOH}$ and $1.5 \mathrm{ml} 0.5 \mathrm{M}$ $\mathrm{HCl}$ ) was added and the mixture was reacted for $5 \mathrm{~min}$ in a water bath at $100^{\circ} \mathrm{C}$. The sample was then analyzed by negative ion LC-APCI-MS as above. The same method was tested on samples of quebracho tannin (kindly supplied by Prof. Ann Hagerman, Miami University, USA), which is dominated by profisetinidins. ${ }^{12}$

\section{Results and discussion}

Extract yields and colorimetric assays of total phenols, flavanols, and tannins

Yields for the large-scale $100 \% \mathrm{MeOH}$ extracts of Acacia mangium were an average of 2.5 times less than for Acacia auriculiformis (Table 1). For both species, of the fractions obtained from these samples, Fr-A (diethyl ether) contained the most extractives. Colorimetric tests revealed that for one sample of both species, flavanols were threefold and tannins were halved in A. auriculiformis when compared with $A$. mangium. Total phenols were an average of twofold higher in A. auriculiformis in than A. mangium for the two samples. In terms of extract yields per unit weight of wood, it was found that the amounts of phenols and tannins in the A. auriculiformis extract were about five times those in the A. mangium extract. While many more samples need to be analyzed to determine variability between different trees grown in different sites, this preliminary information supports the suggestion that phenolic extractives play a role in heart rot susceptibility.

The presence of tannins in both Acacia species was confirmed by the BSA test which showed that fractions B, C, and $\mathrm{D}$ of $A$. mangium had the highest ability to precipitate protein (Table 1). The vanillin- $\mathrm{HCl}$ assay detected flavanols in the $100 \% \mathrm{MeOH}$ extractives of both species but in low amounts (Table 1). This test poorly detects acacia and quebracho-type proanthocyanidins. ${ }^{18,22,23}$ Proanthocyanidins are common in Acacia spp. wood and bark material ${ }^{10}$ but Lange and Hashim ${ }^{24}$ did not detect their presence in the polar extractive fractions of $A$. mangium wood using ethanol-hydrochloric acid. Therefore, it is assumed that the tannins in both Acacia species consist mainly of proanthocyanidins not sufficiently estimated by the vanillin- $\mathrm{HCl}$ assay.

HPLC-MS and NMR identification of flavonoids and proanthocyanidins

HPLC with MS or UV detection revealed that there were three main compounds detectable in both species (compounds I, II, III, see Figs. 2, 3). In A. mangium extracts from Australian or Indonesian trees, compound I was always dominant when detected by MS or UV but in $A$. auriculiformis compound III was the most abundant.

Compounds I, II, and III were purified and identified by NMR as 2,3-trans-3,4',7,8-tetrahydroxyflavanone; 4',7,8trihydroxyflavanone; and teracacidin, respectively. Com- 


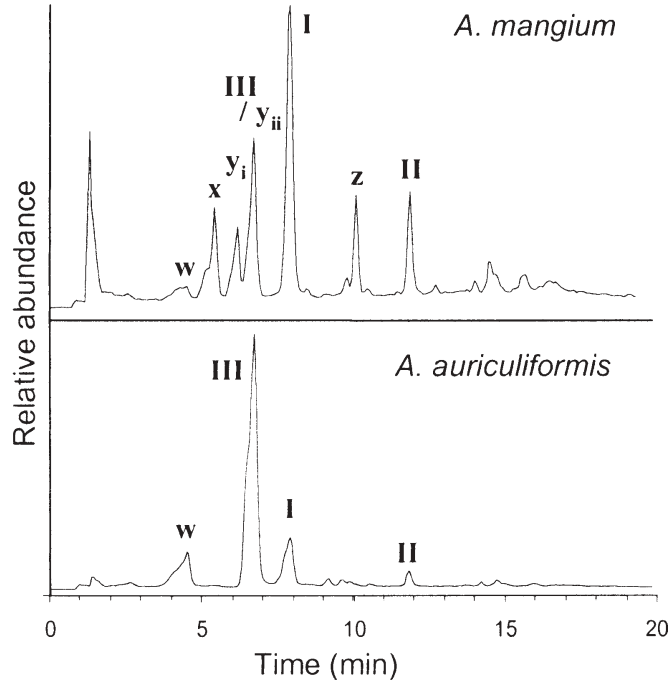

Fig. 2. Positive-ion atmospheric-pressure chemical ionization-MS chromatogram of $100 \% \mathrm{MeOH}$ extracts of $A$. mangium and $A$. auriculiformis heartwoods. I, 2,3-trans-3,4',7,8-tetrahydroxyflavanone; $I I, 4^{\prime}, 7,8$-trihydroxyflavanone; $I I I$, teracacidin; compounds $w, x, y_{i}, y_{i i}, z$, see text

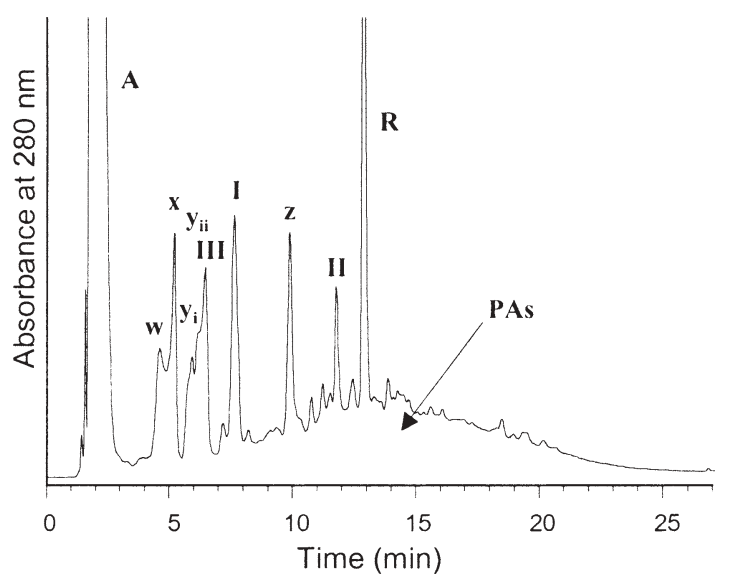

Fig. 3. HPLC-UV chromatogram $(280 \mathrm{~nm})$ of a $70 \%$ acetone extract of $A$. mangium. $A$, acetone; $R$, rutin internal standard; $P A s$, broad proanthocyanidin region

pound I is different to that reported by Tachi et al., ${ }^{13}$ because it is the 2,3-trans-isomer rather than the 2,3-cis-isomer previously reported. Analysis of the extracts by HPLC-MS revealed that while compounds I and II are detected as molecular ions using either APCI or ESI, teracacidin does not form a molecular ion by APCI and only a small amount by ESI. During negative ESI, the molecular ion (290) of teracacidin forms a dimer detected as $[2 \mathrm{M}-\mathrm{H}]^{-}$ions at $m /$ z 579 which constitutes most of the compound. Other ions associated with the compound are $m / z, 153$ and 285 and a small amount of the molecular ion $[\mathrm{M}-\mathrm{H}]^{-}$at $m / z 289$. Using positive-ion APCI, the molecular ion of teracacidin is dehydrated because of the instability of the 3,4-diol and is detected as a $\left[\mathrm{M}-\mathrm{H}_{2} \mathrm{O}+\mathrm{H}\right]^{+}$ion at $m / z$,273, rather than $[\mathrm{M}+\mathrm{H}]^{+}$at $m / z 291$.
Of the minor compounds, the material labeled as $\mathrm{w}$ in Figs. 2 and 3 had identical UV spectra and MS data to teracacidin but had an earlier retention time (see Figs. 2, 3). Isoteracacidin has been previously reported in $A$. auriculiformis ${ }^{15}$ but was identified by paper chromatography and NMR spectroscopy. Because these methods were not used in our studies for compound $\mathrm{w}$ and no pure reference compound is available, identification of compound $\mathrm{w}$ as isoteracacidin cannot be confirmed. The compound labeled as $\mathrm{x}$ was identified as melacacidin, based on comparison with Acacia melanoxylon extracts. Melacacidin (MW 306) is a 3,4-diol (as is teracacidin) and its HPLC-MS behavior (K. Barry and N. Davies, 2001, unpublished data) was previously studied in A. melanoxylon heartwood in which it is the major extractive. ${ }^{20}$ Melacacidin behaves in the same way as teracacidin by forming a dimer of $[2 \mathrm{M}-\mathrm{H}]^{-}$ at $m / z 611$ during negative ESI and a dehydrated ion [M $\left.\mathrm{H}_{2} \mathrm{O}+\mathrm{H}\right]^{+}$at $m / z 289$ during positive APCI. Melacacidin was detected in small amounts in most of the Indonesian $A$. mangium samples and one Australian sample but not in the two Australian A. auriculiformis extracts. Compound w was detected in both $A$. auriculformis samples and all $A$. mangium samples and showed identical ions by APCI and ESI-MS as found for teracacidin. The identification of melacacidin is previously unreported for A. mangium.

Peaks $\mathrm{y}_{\mathrm{i}}$ and $\mathrm{y}_{\mathrm{ii}}$ were routinely found in the extracts of Indonesian $A$. mangium samples but in only one of the Australian samples (Fig. 2). These peaks had $[\mathrm{M}+\mathrm{H}]^{+}$ions at $m / z 305$ when detected by positive-ion APCI and [M $\mathrm{H}]^{-}$ions at $\mathrm{m} / \mathrm{z}, 303$ with negative-ion ESI indicating a MW of 304. The two chromatographic peaks $\left(y_{i}\right.$ and $\left.y_{i i}\right)$ possibly represent two isomeric forms of one compound. The second peak $\left(\mathrm{y}_{\mathrm{ii}}\right)$ coeluted with teracacidin (III; Fig. 2). Lange and Hashim $^{24}$ identified taxifolin (MW 304) in A. mangium apparently by GC-MS, but $\mathrm{y}_{\mathrm{i}}$ and $\mathrm{y}_{\mathrm{ii}}$ have different UV spectra to taxifolin and different HPLC retention times. Compound z (Figs. 2, 3) was detected only in one Australian sample of A. mangium and also remains unidentified.

Proanthocyanin-like compounds were detected as an amalgamation of broad peaks on the HPLC-UV chromatogram (Fig. 3) but were not visible by LCMS (Fig. 2). While the BSA test detected tannins in the acacia extracts, the MW of peaks of PA-like compounds was beyond the detectable mass range of 2000 and therefore they must be large polymers. The depolymerization method used has been successful for a range of proanthocyanidins such as procyanidins ${ }^{21}$ but our test with quebracho revealed that it was not effective for depolymerization of profisetinidin types as the extract remained unchanged. This is probably due to the lack of a 5-hydroxy group. ${ }^{25}$ Negative-ion HPLCAPCI-MS analysis of the depolymerized samples from both species also revealed that the method was not effective in producing tannin products. While pure teracacidin did react during the test, resulting in an $[\mathrm{M}-\mathrm{H}]^{-}$ion at $\mathrm{m} / z 397$ that is representative of a subunit of MW 274 with a phloroglucinol attached (minus two hydrogens for the bond formed), fractions with tannin but no teracacidin (e.g., A. mangium fraction $\mathrm{D}$ ) resulted in no reaction. While this test could not confirm the identity of the tannins, it is possible that they 
Table 2. Concentration of proanthocyanidin-like compounds (PAs), and compounds I and II, $70 \%$ acetone extracts of $A$. mangium

\begin{tabular}{llccc}
\hline & Sapwood & Heartwood & Discoloration & Decay \\
\hline PAs & $5.88(0.92)$ & $15.90(1.26)$ & $34.70(3.47)$ & $10.31(3.81)$ \\
I & 0 & $4.89(1.19)$ & $3.11(0.90)$ & $0.88(0.88)$ \\
II & 0 & $1.37(0.25)$ & $1.07(0.09)$ & $0.24(0.24)$ \\
$n$ & 6 & 6 & 3 & 3 \\
\hline
\end{tabular}

Values in parentheses are $\pm \mathrm{SE}$. Concentrations given in $\mathrm{mg}$ rutin equivalent $\mathrm{g} \mathrm{FW}$ wood $^{-1}$

are quebracho-type tannins in both species. Further method development will be required to verify the nature of the tannins in the Acacia spp. samples.

\section{Quantification by HPLC-UV}

Two of the major flavonoids were quantified in the Indonesian $A$. mangium extracts in terms of rutin equivalents with UV detection at $280 \mathrm{~nm}$ (Table 2). Compound I was detected in the highest amount at this wavelength, followed by II. Teracacidin (III) is poorly detected at this wavelength in comparison with the other compounds and, with the added complication of coelution with compound $\mathrm{y}_{\mathrm{ii}}$, was not quantified. In all cases none or negligible amounts of I and II were found in the sapwood. Heartwood and discolored samples had the highest concentrations in all cases and showed no statistically significant differences when compared. The decayed wood had significantly lower concentrations of each compound suggesting that the compounds are degraded during the decay process.

Semiquantification of PA-like polymers in A. mangium was possible by integration of the characteristic amalgamation of compounds detected by HPLC-UV (Fig. 3) that were beyond the MS detection limits. The concentration of the PA-like compounds was significantly higher in the discolored wood. The heartwood had concentrations that were two-fold higher than the sapwood (Table 2). In contrast to the flavonoids (Table 2), the relative concentration of proanthocyanidins in the decayed wood was not decreased as much in proportion to the heartwood. That is, the concentration of compound I was ca. sixfold less in the decayed wood compared with heartwood, while the proanthocyanidins were only 1.5 -fold less. This indicates that the proanthocyanidins are degraded to a lesser extent than the flavonoids in the decay process and supports a bioactive role for these compounds as discussed above.

\section{Conclusions}

The conclusions of this study are:

1. The heartwood of both species contains similar types of flavonoids.

2. The quantity of total phenols is approximately fivefold higher in Acacia auriculiformis than in Acacia mangium.
3. A similar amount of tannins was detected in $A$. auriculiformis wood compared with $A$. mangium; therefore, monomeric phenolics such as flavonoids may contribute to the relative heart rot resistance of $A$. auriculiformis compared with $A$. mangium.

4. The flavonoids I and II are degraded in A. mangium during the decay process, while the proanthocyanins are degraded to a lesser extent. The contribution of the components of the phenolic extracts to the heart rot resistance has been further explored with bioassays of heartrot fungi. ${ }^{28}$

Acknowledgments This research was funded by the Australian Centre of International Agricultural Research. A visit by Ms. Rie Mihara to Tasmania was funded by the Japanese Academic Frontiers Student Exchange Promotion Program. We are grateful to David Lee for access and assistance at the Meunga trial and Ragil Irianto for assistance at the Indonesian field sites and help with extractions. Preliminary NMR work was performed by Dr. Evan Peacock (University of Tasmania). Professor Ann Hagerman and Dr. Alieta Eyles provided useful comments on an earlier version of this manuscript.

\section{References}

1. FAO (2000) Forestry: country profiles. http://www.fao.org/ forestry/. Cited on May 3, 2004

2. Lee SS, Teng SY, Lim MT, Razali AK (1988) Discoloration and heartrot of Acacia mangium Willd. - some preliminary results. J Trop For Sci 1:170-177

3. Old KM, Lee SS, Sharma JK, Yuan ZQ (2000) A manual of diseases of tropical Acacias in Australia, South East Asia, and India. Centre for International Forestry Research, Jakarta, p 104

4. Barry KM, Irianto RSB, Santoso E, Turjaman M, Widyati E, Sitepu I, Mohammed CL (2004) Incidence of heart rot in harvestage Acacia mangium in Indonesia, using a rapid survey method. For Ecol Manage 190:273-280

5. Ito S, Nanis LH (1997) Survey of heartrot on Acacia mangium in Sabah, Malaysia. JARQ 31:65-71

6. Ito S (2002) The infection of heartrot and disease severity on several Acacia species in SAFODA plantations. Study Report of SAFODA-JICA Project, $\mathrm{p} 16$

7. Mahmud S, Lee SS, Ahmad HH (1993) A survey of heartrot in some plantations of Acacia mangium Willd. in Sabah. J Trop For Sci 6:37-47

8. Hillis WE (1987) Heartwood and tree exudates. Springer, Berlin Heidelberg New York, p 268

9. Taylor AM, Gartner BL, Morrell JJ (2002) Heartwood formation and natural durability - a review. Wood Fiber Sci 34:587-611

10. Seigler DS (2003) Phytochemistry of Acacia - sensu lato. Biochem Syst Ecol 31:845-873

11. Foo LY (1984) Condensed tannins: co-occurrence of procyanidins, prodelphinidins and profisetinidins in the heartwood of Acacia baileyana. Phytochemistry 12:2915-2918 
12. Pasch H, Pizzi A, Rode K (2001) MALDI-TOF mass spectrometry of polyflavonoid tannins. Polymer 42:7531-7539

13. Tachi M, Tange J, Nagadomi W, Suzuki Y, Terashima N, Yasuda S (1989) Manufacture of wood-cement boards. IV. Cementhardening inhibitory components of the Malaysian fast-growing tree, Acacia mangium. Mokuzai Gakkaishi 35:731-735

14. Pietarinen SP, Willför SM, Sjöholm RE, Holmbom BR (2004) Extractives in Acacia mangium and Acacia crassicarpa stemwood and knots. Proceedings of the 58th Appita Conference, 19-21 April 2004, Canberra, pp 557-563

15. Drewes SE, Roux DG (1966) A new flavan-3,4-diol from Acacia auriculiformis by paper ionophoresis. Biochem J 98:493500

16. Nikles DG, Harwood CE, Robson KJ, Pomroy PC, Keenan RJ (1998) Management and use of ex situ genetic resources of some tropical Acacia species in Queensland. In: Turnbull JW, Crompton HR, Pinyopusarerk K (eds) Recent developments in acacia planting. ACIAR proceedings No. 82, Canberra, pp 184-196

17. Barry KM, Davies NW, Mohammed CL (2002) Effect of season and different fungi on phenolics in response to xylem wounding and inoculation in Eucalyptus nitens. For Path 32:163-178

18. Mitsunaga T, Doi T, Kondo Y, Abe I (1998) Color development of proanthocyanidins in vanillin-hydrochloric acid reaction. J Wood Sci 44:125-130
19. Kawamoto H, Mizutani K, Nakatsubo F (1997) Binding nature and denaturation of protein during interaction with galloylglucose. Phytochemistry 43:473-478

20. Barry KM, Davies NW, Mohammed CL, Beadle CL (2003) Postharvest chemical staining in blackwood (Acacia melanoxylon $\mathrm{R}$. Br.). Holzforschung 57:230-236

21. Pascual-Teresa S, Treutter D, Rivas-Gonzalo JC, Santos-Buelga C (1998) Analysis of flavanols in beverages by high-performance liquid chromatography with chemical reaction detection. J Agric Food Chem 46:4209-4213

22. Hagerman A (2002) Tannin handbook http://www.users.muohio. edu/hagermae/. Cited on February 1, 2003

23. Schofield P, Mbugua DM, Pell AN (2001) Analysis of condensed tannins: a review. Anim Feed Sci Technol 91:21-40

24. Lange W, Hashim R (2001) The composition of the extractives from unaffected and heartrot-affected heartwood of Acacia mangium Willd. Holz Roh Werkst 5:61-66

25. Jacquet G, Matthews S, Deprez S, Pollet B, Mila I, Lapierre C, Scalbert A (1997) Thiolysis and thioacidolysis: recent progress in the characterisation of phenolic polymers. Analusis 25:26-29

26. Mihara R, Barry KM, Mohammed CL, Mitsunaga T (2005) Comparison of antifungal and antioxidant activities of Acacia mangium and $A$. auriculiformis heartwood extracts. J Chem Ecol 31:789804 